\title{
Pengaruh strategi komunikasi pemasaran Starbucks Card terhadap loyalitas konsumen \\ (Studi Pada Konsumen Berstatus Mahasiswa PT. Starbucks Coffee di Kota Bandung)
}

\author{
Kartika Sari ${ }^{1}$, Nurhayati, I.K ${ }^{2}$ \\ ${ }^{1,2}$ Fakultas Komunikasi dan Bisnis, Universitas Telkom, Bandung, Indonesia \\ ${ }^{1}$ kartikaasb@gmail.com, ${ }^{2}$ iiskurnia@gmail.com
}

\begin{abstract}
ABSTRAK
Loyalitas memiliki peranan penting demi majunya suatu perusahaan khususnya dalam persaingan industri kedai kopi saat ini. Perusahaan menerapkan berbagai strategi komunikasi pemasaran demi mempertahankan konsumennya dalam menggunakan produk dan jasa. Penelitian ini dilakukan untuk menguji pengaruh strategi komunikasi pemasaran Starbucks Card terhadap loyalitas konsumen berstatus mahasiswa di kota Bandung. Penelitian ini melakukan teknik sampling yang akan digunakan yaitu dengan cara non-probability sampling dikarenakan tidak adanya data sekunder yang menjelaskan secara tepat jumlah konsumen yang menggunakan Starbucks Card sehingga jumlah sampel yang dimiliki yaitu 105 responden. Berdasarkan dari hasil data pengolahan, dapat dilihat bahwa sub variabel yang paling berpengaruh positif terhadap loyalitas konsumen yaitu promosi penjualan, personal selling serta direct marketing dan pemasaran via internet yang berada pada kategori baik. Strategi komunikasi pemasaran yang telah dilakukan oleh Starbucks Coffee guna meningkatkan loyalitas konsumen dalam menggunakan kartu member Starbucks telah berjalan dengan baik dan memiliki respon yang baik oleh para penggunanya sehingga saran yang dapat diberikan yaitu mempertahankan hal tersebut agar dapat mempertahankan konsumen yang loyal maupun untuk menarik konsumen baru.
\end{abstract}

Kata Kunci: Loyalitas Konsumen, Strategi Komunikasi Pemasaran, Starbucks Card, PT. Starbucks Coffee, Mahasiswa.

\begin{abstract}
Loyalty has an important role for the sake of growth in a company, especially in the competitive coffee industry nowadays. A company implements variety of marketing communications strategy in order to maintain their customers in using products and services. This research is conducted to examine the influence of the marketing communication strategy of Starbucks Card toward customer loyalty in college student in Bandung. This research's sampling technique uses nonprobability sampling due to the lack of secondary data specifying exactly the number of consumers who use the Starbucks Card so the sample sizes are 105 respondents. Based on the results of data processing, it can be seen that the subvariables that have the most positive effect on customer loyalty are sales promotion, personal selling, direct marketing and marketing via the internet which are among good categories..Marketing communications strategy that has been done by Starbucks Coffee to increase consumer loyalty in using Starbucks Card has gone well and has a good response by the users so the suggestion that can be
\end{abstract}


given is to retain it in order to maintain loyal customers and to attract new customers.

Keywords: Consumer Loyalty, Marketing Communications Strategy, Starbucks Card, PT. Starbucks Coffee, College Student.

\section{PENDAHULUAN}

Setiap perusahaan melakukan promosi produk atau jasanya dengan tujuan agar adanya feedback yang baik berupa hubungan jangka panjang dengan konsumennya. Namun untuk mewujudkan impian tersebut, tentunya perusahaan harus membuat strategi komunikasi pemasaran agar produk atau jasanya menjadi brand top of mind dibenak konsumen. Strategi komunikasi pemasaran atau yang biasa disebut dengan bauran promosi ini meliputi periklanan, promosi penjualan, personal selling, public relation, direct marketing maupun pemasaran via internet. Keberadaan internet khususnya website yang semakin banyak digunakan saat ini, sehingga menjadi suatu fenomena dalam menjalin komunikasi terutama dalam pemasaran (Harist, 2012). Perannya sangat vital mengingat peran komunikasi dalam memfasilitasi hubungan saling menguntungkan antara perusahaan dengan pelanggan. Berkat perkembangan ilmu pemasaran, tujuan komunikasi kini tak lagi terbatas untuk mendorong pembelian pertama, namun juga memastikan kepuasan paska pembelian sehingga meningkatkan kemungkinan terjadinya pembelian secara berulang dan pelanggan tersebut menjadi pelanggan yang loyal (loyalitas konsumen).

Penelitian ini akan mengambil salah satu perusahaan yang menerapkan bauran promosi yaitu Starbucks Coffee Indonesia. Starbucks Coffee masuk ke negeri Indonesia pada tahun 2000 dengan membuka gerai pertamanya di Plaza Indonesia, Jakarta. Perusahaan ini mewakilkan lisensi dan pengelolaan bisnis di tanah air kepada PT Sari Coffee Indonesia. Starbucks Coffee melakukan beberapa bentuk komunikasi pemasaran dalam menawarkan produk yang dimilikinya kepada konsumen dan calon konsumennya, terutama dalam mempromosikan produk yang dikemas dalam bentuk kartu member atau reward loyalty program. Elemen tersebut meliputi kegiatan periklanan, hubungan masyarakat, promosi penjualan, penjualan secara personal, penjualan langsung serta pemasaran via internet berupa penggunaan social media seperti Instagram, Facebook serta Twitter untuk mempromosikan berbagai keuntungan yang ditawarkan oleh kartu member ini.Namun, menurut Anthony Cottan selaku Direktur Starbucks Coffee Indonesia mengatakan bahwa dua elemen yang paling melekat untuk mempromosikan Starbucks Card yaitu secara personal selling dan pemasaran via Internet (Arini, 2013). Hal ini dibuktikan dengan pada hari pertama peluncuran Starbucks Card dari lima besar dengan aktivasi tertinggi peringkat pertama ditempati oleh DKI Jakarta sebesar 63.9\% diikuti oleh Jawa barat sebesar 8.72\%, Jawa Timur $8.37 \%$, Banten 7.6\%, dan Bali 3.22\% .

Berdasarkan hasil survei citra Kota Bandung yang dilakukan oleh Kompas.com, menjelaskan bahwa Kota Bandung identik dengan kota kuliner (Wardhani, 2010). Sejak tahun 2006, Kota Bandung mulai bermunculan kedai kopi dari negara asing seperti Starbucks Coffee maupun usaha kopi lokal seperti Ngopi Doeloe. Fenomena ini diperkuat dengan adanya hasil survei oleh Pikiran Rakyat yang membuktikan bahwa pemesanan kopi di Bandung meningkat sebesar 20\% dikarenakan semakin banyak nya peminat kopi di kota Bandung (Solihat, 2016). Sedangkan untuk Starbucks Coffee 
sendiri, saat ini tersebar secara merata di seluruh Indonesia sebayak 151 gerai termasuk 5 gerai di Kota Bandung. Berdasarkan letak gerai tersebut, terlihat bahwa konsumen yang dibidik adalah pebisnis dan kalangan atas. Namun menurut pengakuan dari Anthony Cottan, dalam beberapa tahun terakhir telah terjadi pergeseran konsumen. Mereka yang datang ke seluruh gerai Starbucks di Indonesia didominasi oleh kalangan yang berumur 18 - 35 tahun membuktikan bahwa tidak hanya kalangan pebisnis saja yang mengunjungi gerai Starbucks melainkan para pelajar dan mahasiswa. (Prasetyo, 2013). Selain itu, berdasarkan survey yang dilakukan oleh Koran Sindo, diketahui bahwa kota Bandung merupakan salah satu daerah yang diminati calon mahasiswa karena terkenal dengan dunia pendidikannya, dimana setiap tahun terdapat kurang lebih 500.000 mahasiswa yang mendaftarkan dirinya di perguruan swasta dan negeri di kota Bandung (Rufaidah, 2016). Menurut Elly (2012:188) beberapa ciri khas pola perilaku mahasiswa. Pertama, kehidupan dikota-kota besar dengan limpahan saraa informasi dan hiburan menuntut kaum mahasiswa menjadi rentan terhadap nilai-nilai baru. Kedua, salah satu kebutuhan kaum remaja maupun mahasiswa adalah sosialisasi diri dalam pergaulan sebayanya. Maka tidak jarang coffee shop menjadi tempat yang dituju untuk memenuhi kebutuhan ini. Ketiga, maraknya tempat-tempat berupa kafe di kota besar yang menjadi perhatian utama salah satunya di Kota Bandung. Di Bandung, selain terkenal sebagai kota pelajar, kota ini terkenal dengan kota kuliner.

Berdasarkan hasil penelitian yang lakukanoleh Rendy mengenai Penilaian Konsumen Untuk Mengukur Ekuitas Merek di Kota Bandung tahun 2011, menunjukkan bahwa Starbucks Coffee di Kota Bandung merupakan kedai kopi yang paling diminati oleh masyarakat di kota Bandung dengan jumlah responden yakni sebanyak 62,2\% (239 dari 284 responden) pada tahun 2011.

Starbucks Coffee selalu mengedepankan kualitas produk dan pelayanannya terutama dalam hal mempromosikan produknya.Produk-produknya diklaim memiliki kualitas yang baik dan para pekerjanya selalu dilatih memberikan pelayanan sebaik-baiknya terhadap konsumen. Starbucks Coffee menciptakan sebuah strategi penjualan berupa reward loyalty program yang dikemas kedalam bentuk Starbucks Card. Starbucks Card merupakan strategi khusus yang dilakukan Starbucks Coffee untuk mempertahankan loyalitas konsumennya selain dengan cara membuka gerai baru (Prasetyo, 2013). Inovasi peluncuran Starbucks Card pertama kali di Indonesia pada tahun 2013 dengan tujuan untuk memudahkan pelanggan setia mereka dalam bertransaksi di seluruh gerai Starbucks Cofee termasuk seluruh gerai di Kota Bandung. Starbucks Coffee Indonesia menjelaskan bahwa Starbucks Card diciptakan untuk konsumen yang sudah loyal dengan Starbucks Coffee dimana memiliki fungsi yakni hampir sama dengan kegunaan kartu debit, namun keunggulan yang dimiliki Starbucks Coffee yaitu adanya benefit yang berbeda bagi para penggunanya. Selain itu, Starbucks Coffee juga meluncurkan aplikasi digital dimana pemegang kartu Starbucks dapat mengecek saldo kartu, top-up, serta mengetahui menu yang tersedia di gerai yang diharapkan agar dapat lebih mendekatkan diri dengan pelanggan setianya (Arini, 2013). Aplikasi digital ini merupakan aplikasi berbasis Android dan IOS untuk para pengguna Starbucks Card yang telah melakukan registrasi sebelumnya dan dapat $\log$ in di aplikasi tersebut. Aplikasi ini tentunya diharapkan agar konsumen yang menggunakan member card tersebut tidak perlu mengantre untuk melakukan transaksi pembelian. Selain itu, 
aplikasi ini memiliki barcode yang sama tertera dalam kartu tersebut sehingga memudahkan konsumen untuk bertransaksi (Ratna, 2016).

Fenomena pengunaan Starbucks Card atau kartu member untuk pelanggan setia Starbucks Coffee ini membuat konsumen memiliki ketertarikan untuk menggunakannya. Fenomena ini diperkuat dengan adanya penjelasaan dari Anthony Cottan selaku Direktur Starbucks Indonesia yang menjelaskan bahwa konsumen yang menggunakan Starbucks Card merupakan masyarakat yang sudah berpikiran modern sehingga adanya ketertarikan untuk menerima kehadiran kartu ini dengan baik karena adanya kemudahan dalam bertransaksi. Disamping memberikan kemudahan konsumen untuk bertransaksi, Starbucks Card ini memiliki desain yang unik. Desain yang unik tersebut membuat konsumen Starbucks Coffee dapat mengoleksi kartu tersebut dalam cukup satu akun member saja.Selain itu, pemegang kartu ini juga akan mendapatkan beberapa benefit atau penawaran seperti gratis minuman berukuran grande untuk setiap pembelian 10 minuman dan selalu mendapatkan kesempatan pertama untuk dapat mengoleksi merchandise edisi terbaru berupa tumbler, bags, Starbucks Card new edition sebelum merchandise tersebut dipasarkan untuk umum. Salah satu quote yang dikutip oleh Howard Schuta selaku Kepala Starbucks Coffee "The Starbucks Card is the most significant new product since Frappucino". (Duffy, 2003:483)

Berikut data transaksi Starbucks Card di seluruh gerai Starbucks Coffee Bandung pada bulan April 2014 setiap hari Sabtu dan Minggu. Data ini diperoleh dari peneliti terdahulu yang berjudul Pengaruh Kualitas Pelayanan Starbucks Coffee Terhadap Kepuasan Pelangan di Bandung oleh Barry Ibnu Firmanda. Berdasarkan data dari penelitian tersebut, diketahui bahwa gerai Starbucks Coffee di kota Bandung dengan urutan pertama yaitu di Paris Van Java dengan nilai 3,460. Kemudian Starbucks Coffee di Bandung Indah Plaza mendapati urutan kedua dengan total 2,672. Lalu Starbucks Trans Studio Mall urutan ketiga dengn nilai 2,568 dan Starbucks Braga City Walk dan Starbuck Cihampelas Walk untuk urutan ke empat dan lima dengan nilai 2,473 dan 2,433 .

Kotler dan Keller (2006 : 153) mengatakan bahwa menciptakan hubungan yang kuat dan erat dengan pelanggan adalah mimpi semua pemasar dan hal ini sering menjadi kunci keberhasilan pemasaran jangka panjang. Tujuan dari setiap perusahaan saat ini yakni lebih fokus dalam meningkatkan suatu loyalitas konsumen. Peranan komunikasi pemasaran sangat vital mengingat peran komunikasi sebagai memfasilitasi hubungan antara perusahaan dengan pelanggan. Dimana tujuan komunikasi tak hanya untuk mendorong pembelian pertama, namun juga memastikan kepuasan paska pembelian sehingga besar kemungkinan terjadinya pembelian secara berulang atau loyalitas konsumen. Loyalitas konsumen sendiri merupakan suatu kegiatan yang dilakukan konsumen agar terjadinya transaksi pembelian berulang atau pembelian kembali.

Berdasarkan uraian penjelasan diatas, penulis mencoba untuk melakukan penelitian mengenai Pengaruh Strategi Komunikasi Pemasaran Starbucks Card terhadap Loyalitas Konsumen dikarenakan masih dikitnya penelitian yang menjadikan Starbucks Card sebagai objek penelitian. Selain itu, penulis mencoba untuk mengetahui adakah pengaruh strategi komunikasi pemasaran yang terdapat dalam Starbucks Card. Selain itu, penulis ingin mengetahui mengenai seberapa besarpengaruh strategi komunikasi pemasaran yang terdapat dalam Starbucks Card terhadap loyalitas konsumen terutama di kalangan mahasiswa di Kota Bandung.Maka dari itu, penulis mengadakan penelitian 
mengenai "Pengaruh Strategi Komunikasi Pemasaran Starbucks Card Terhadap Loyalitas Konsumen(Studi Pada Konsumen Berstatus Mahasiswa PT. Starbucks Coffee Cabang Bandung"

\section{METODE PENELITIAN}

Penelitian ini termasuk kedalam penelitian eksplanatif. Penelitian ini dilakukan pada konsumen berstatus mahasiswa yang menggunakan Starbucks Card di Kota Bandung. Jumlah sampel yang dimiliki sebanyak 105 orang. nonprobability sampling adalah teknik pengambilan sampel yang tidak memberi peluang atau kesempatan sama bagi setiap unsur atau anggota populasi untuk dipilih menjadi sampel. Dalam nonprobability sampling, cara pengambilannya dilakukan dengan purposive sampling. Pengumpulan data dilakukan melalui penyebaran kuisioner ke sejumlah mahasiswa yang tersebar di Kota Bandung. Pengukuran data menggunakan skala Likert dengan lima kriteria penilaian dan menggunakan analisis regresi linear berganda. Untuk menentukan jumlah responden pada kuisioner penelitian dikarenakan jumlah populasi yang terlalu banyak dan tidak dapat diketahui, maka penulis menggunakan metode Bernoulli (Sedarmayanti, 2002: 149):

Dimana: $\mathrm{n}=$ jumlah sampel

$$
n=\frac{\left(Z \frac{\alpha}{2}\right)^{2} \rho X q}{e^{2}}
$$

$$
\mathrm{Z}=\text { nilai yang didapat dari table normal standar dengan peluang } \frac{\alpha}{2}
$$

$\mathrm{p}=$ probabilitas populasi yang tidak diambil sebagai sampel

$$
\begin{aligned}
& q=\text { probabilitas populasi yang diambil sebagai sampe; (1-p) } \\
& \propto=\text { tingkat ketelitian } \\
& \mathrm{e}=\text { tingkat kesalahan }
\end{aligned}
$$

Dalam penelitian ini, peneliti menggunakan tingkat signifikansi atau ketelitian $(\propto)$ sebesar 5\% dan tingkat kepercayaan penelitian 95\% dengan standard error $\mathrm{Z}=1,96$ dengan nilai e sebesar $10 \%$. Probabilitas populasi masing-masing sebesar 0,5. Sehingga nilai-nilai tersebut dapat dihitung ukuran sampel sebagai berikut:

$$
\begin{gathered}
n=\frac{\left(Z \frac{\alpha}{2}\right)^{2} \rho X q}{e^{2}} \\
n=\frac{(1,96)^{2} X 0,5 \times 0,5}{0,1^{2}} \\
n=\mathbf{9 6 , 0 4}
\end{gathered}
$$

Maka, jumlah sampel yang dapat diolah minimal sebesar 96 responden.

Teknik Analisis Data

Dalam penelitian kuantitatif, analisis data digunalan setelah peneliti memperoleh data dan informasi dari hasil pengisian kuisoner. Kegiatan dalam analisis data berupa melakukan uji validitas dan realibilitas.Lalu, data akan diseleksi sesuai dengan variable dan klasifikasi variable. Kemudian data tersebut ditabulasi dengan menggunakan SPSS 21.0 for Windows. Data tersebut akan diolah dan mendapatkan informasi deskriptif dan pengujian hipotesis. 


\section{Analisis Statistik Deskriptif}

Analisis statistik deskriptif merupakan analisis statistik yang digunakan untuk menganalisis data dengan cara mendeskripsikan atau menggambarkan data yang telah terkumpul sebagaimana adanya tanpa bermaksud membuat kesimpulan (Sugiyono, 2016: 147). Statistik deskriptif digunakan apabila peneliti hanya ingin mendeskripsikan data karakteristik sampel. Pada analisa deskriptif secara demografi akan diuraikan mengenai jenis kelamin, usia, serta pengeluaran perbulan responden berbelanja di Starbucks Coffee Bandung dengan menggunakan Starbucks Card.

Dari jawaban responden kemudian akan disusun kriteria penilaian untuk setiap butir pertanyaan berdasarkan persentase dengan langkah-langkah sebagai berikut (Arikunto, 2010: 269):

a. Nilai kumulatif adalah jumlah nilai dari setiap pernyataan yang merupakan jawaban dari setiap responden.

b. Persentase adalah nilai kumulatif item atau butir pertanyaan dibagi dengan nilai frekuensinya dikalikan $100 \%$

c. Jumlah responden yang peneliti ambil adalah 105 orang. Nilai skala pengukuran terbesar adalah 5, sedangkan skala pengukuran terkecil adalah 1 . Sehingga diperoleh jumlah kumulatif sebesar $105 \times 5=525$, dan jumlah kumulatif terkecil $105 \times 1=105$. Adapun nilai persentase terbesar adalah $(525: 525) \times 100 \%=100 \%$, sedangkan nilai persentase terkecil adalah $(105: 252) \times 100 \%=20 \%$. Nilai rentang $=100 \%-20 \%=80 \%$. Jika dibagi 5 skala pengukuran maka didapat nilai interval sebesar $16 \%$.

Berdasarkan perhitungan tersebut maka dapat diperoleh nilai-nilai kriteria interpretasi skor yang dapat dilihat pada tabel dibawah ini: 
Tabel 1 Presentase Kriteria Penilaian Kuisioner

\begin{tabular}{|l|l|}
\hline Persentase & Kategori Persentase \\
\hline $20 \%-36 \%$ & Sangat Tidak Setuju \\
\hline$>36 \%-52 \%$ & Tidak Setuju \\
\hline$>52 \%-68 \%$ & Netral \\
\hline$>68 \%-84 \%$ & Setuju \\
\hline$>84 \%-100 \%$ & Sangat Setuju \\
\hline \multicolumn{2}{|c|}{ Sumber: Data olahan peneliti }
\end{tabular}

Perhitungan skor total untuk masing-masing indikator variabel adalah sebagai berikut:

Skor total $=($ jumlah responden sangat setuju $\mathrm{x} 5)+($ jumlah reponden setuju $\mathrm{x} 4)$ $+($ jumlah responden netral $\mathrm{x} 3$ ) + (jumlah responden tidak setuju $\mathrm{x} 2)+($ jumlah responden sangat tidak setuju x 1).

Skor ideal $($ diasumsikan $)=$ seluruh responden menjawab sangat setuju $\mathrm{x}$ jumlah responden.

Selanjutnya untuk melihat hasil dari nilai total setiap variabel, maka dapat dilihat pada garis kontinum dibawah ini (Gambar 1):

\section{Gambar 1 Garis Kontinum Kriteria Penliaian Kuisioner}

\begin{tabular}{|l|c|c|c|c|}
$\begin{array}{c}\text { Sangat } \\
\text { Tidak }\end{array}$ & $\begin{array}{c}\text { Tidak } \\
\text { Setuiu }\end{array}$ & Netral & Setuju & $\begin{array}{c}\text { Sangat } \\
\text { Setuiu }\end{array}$ \\
\hline $20 \%$ & & & & \\
$52 \%$ & $68 \%$ & $84 \%$ & $100 \%$
\end{tabular}

Sumber: Data olahan peneliti

Setelah kegiatan tersebut, peneliti akan melakukan uji instrument untuk melihat validitas dan reliabilitas dari kuisioner.

Uji Asumsi Klasik

Menurut Suliyanto (2011: 69-147), uji asumsi klasik memiliki tujuan yaitu untuk memberikan kepastian bahwa persamaan regresi yang didapatkan memiliki ketepatan dalam estimasi dan konsisten. Berikut beberapa jenis uji asumsi klasik yang akan digunakan dalam penelitian ini:

1. Uji Normalitas

Uji normalitas dimaksudkan untuk menguji apakah nilai residual yang telah distandarisasi pada model regresi bertribusi normal atau tidak. Nilai residual dikatakan berdistribusi normal jika nilai residual terstandarisasi tersebut sebagian besar mendekati nilai rata-ratanya. Penelitian ini menggunakan uji normalitas dengan analisis grafik, dimana pengujian normalitas ini dilakukan dengan menggunakan histogram dengan menggambarkan variabel dependent sebagai sumbu vertical sedangkan nilai residual terstandarisasi digambarkan sebagai sumbu horizontal. Jika 
Histogram Standardized Regression Residual membentuk kurva seperti lonceng maka nilai residual tersebut dikatakan normal.

2. Uji Heteroskedastisitas

Uji heteroskedastisitas berarti ada varian variabel pada model regresi yang tidak sama (konstan). Sebaliknya, jika varian variabel pada model regresi memiliki nilai yang sama (konstan) maka disebut dengan homoskedastisitas. Masalah heteroskedastisitas biasanya terjadi dalam penelitian yang menggunakan data cross-section. Pada penelitian ini akan menggunakan uji asumsi klasik heteroskedastisitas dengan analisis grafik.

3. Uji Lineritas

Pengujian lineritas ini perlu dilakukan untuk mengetahui model yang dibuktikan merupakan model linier atau tidak. Hasil dari uji lineritas ini adalah informasi mengenai apakah model empiris sebaiknya linier, kuadrat ataupun kubik. Penelitian ini akan menggunakan uji lineritas dengan metode analisis grafik. Metode analisis grafik dilakukan dengan mengamati scarletterplot di mana sumbu horizontal menggambarkan nilai prediksi terstandarisasi sedangkan sumbu vertikal menggambarkan nilai residual terstandarisasi.

\section{Hasil Pretest}

Peneliti melakukan pretest untuk menguji kelayakan instrument yang akan digunakan sebelum melakukan penyebaran dan pengumpulan data kepada responden dalam jumlah besar. Pretest dilakukan dengan cara menyebarkan kuisioner kepada responden yang memiliki karakteristik yang sama yakni pelanggan Starbucks Coffee yang melakukan transaksi pembayaran dengan menggunakan Starbucks Card. Jumlah responden dalam pretest ini sebanyak 31 orang. Tujuan pretest dilakukan untuk mengetahui apakah kalimat pertanyaan dalam kuisioner sudah dipahami sehingga memudahkan responden untuk menjawab pertanyaan yang disediakan.

1. Validitas Indikator Penelitian

Validitas dari masing-masing indikator dilakukan dengan uji Pearson untuk setiap indikator. Dengan jumlah responden sebanyak 31 orang dengan signifikansi 5\%, maka didapatkan nilai $\mathrm{df}=\mathrm{n}-2$ atau $\mathrm{df}=31-2=29$. Apabila dilihat dari tabel $\mathrm{r}$, maka $\mathrm{r}$ product moment dari signifikansi 5\% adalah nilai $\mathrm{r}$ tabel $=0,3550$.

Tabel 2

Validitas Indikator Pengukuran $(\mathrm{n}=31)$

\begin{tabular}{|c|c|c|c|}
\hline $\begin{array}{c}\text { No Item } \\
\text { Pertanyaan }\end{array}$ & $\begin{array}{c}\text { Nilai } \\
\text { Korelasi }\end{array}$ & $\begin{array}{c}\text { Standar } \\
\text { Validitas }\end{array}$ & Valid \\
\hline 1 & 0,759 & 0,3550 & Valid \\
\hline 2 & 0,882 & 0,3550 & Valid \\
\hline 3 & 0,770 & 0,3550 & Valid \\
\hline 4 & 0,623 & 0,3550 & Valid \\
\hline 5 & 0,524 & 0,3550 & Valid \\
\hline 6 & 0,692 & 0,3550 & Valid \\
\hline 7 & 0,608 & 0,3550 & Valid \\
\hline 8 & 0,826 & 0,3550 & Valid \\
\hline
\end{tabular}




\begin{tabular}{|c|c|c|c|}
\hline 9 & 0,722 & 0,3550 & Valid \\
\hline 10 & 0,751 & 0,3550 & Valid \\
\hline 11 & 0,790 & 0,3550 & Valid \\
\hline 12 & 0,877 & 0,3550 & Valid \\
\hline 13 & 0,707 & 0,3550 & Valid \\
\hline 14 & 0,774 & 0,3550 & Valid \\
\hline 15 & 0,549 & 0,3550 & Valid \\
\hline 16 & 0,633 & 0,3550 & Valid \\
\hline 17 & 0,571 & 0,3550 & Valid \\
\hline 18 & 0,599 & 0,3550 & Valid \\
\hline 19 & 0,634 & 0,3550 & Valid \\
\hline 20 & 0,895 & 0,3550 & Valid \\
\hline 21 & 0,793 & 0,3550 & Valid \\
\hline
\end{tabular}

Sumber: Olahan Peneliti (2016)

Berdasarkan tabel 2 terlihat bahwa nilai $\mathrm{r}$ hitung pada semua item pertanyaan menunjukkan angka lebih besar dari $\mathrm{r}$ kritis $(0,3550)$ sehingga dapat disimpulkan bahwa semua item tersebut telah valid dan dapat dipergunakan dalam penelitian.

2. Reliabilitas Variabel Penelitian

Uji reliabilitas digunakan untuk mengetahui sejauh mana pengukuran memberikan hasil yang konsisten. Nilai batas reliabilitas dengan menggunakan Cronbach's Alpha yang biasanya diterima secara umum adalah 0.60. Berdasarkan hasil pengujian reliabilitas dengan menggunakan SPSS 21 for Windows, dapat diketahui bahwa nilai Cronbach's Alpha dalam penelitian ini sudah memenuhi syarat, yaitu nilainya diatas 0.60 .

Tabel 3

Hasil Uji Reliabilitas

Reliability Statistics

\begin{tabular}{|r|r|}
\hline $\begin{array}{c}\text { Cronbach's } \\
\text { Alpha }\end{array}$ & N of Items \\
\hline, 950 & 21 \\
\hline
\end{tabular}

Berdasarkan data dari tabel 3, dapat diketahui bahwa 21 item pertanyaan yang digunakan dalam penelitian ini telah reliable dan dapat digunakan karena nilai Cronbach Alpha dari 21 pertanyaan yang digunakan > 0,60 yaitu sebesar 0,950.

\section{HASIL DAN PEMBAHASAN}

Penelitian ini menyebar kuisioner ke lapangan sehingga mendapat tanggapan sebanyak 164 responden, namun melalui screening question yang tercantum di kuisioner sehingga yang tidak sesuai karakteristik responden yang dibutuhkan akan dihapus sehingga peneliti mendapatkan 105 responden sesuai dengan karakteristik penelitian yaitu berdasarkan apakah responden berdomisili di Kota Bandung, apakah responden berstatus mahasiswa, apakah responden mengetahui Starbucks Card dan apakah responden menggunakan Starbucks Card. Pengumpulan data pada penelitian ini dilakukan pada bulan November-Desember 2016. Responden dalam penelitian ini 
adalah konsumen yang berstatus mahasiswa yang menggunakan Starbucks Card di Kota Bandung.

\section{Karakteristik Responden}

1. Jenis Kelamin Responden

Dari 105 responden dalam penelitian ini, terdapat 33 (31\%) yang merupakan responden laki-laki dan $72(69 \%)$ yang merupakan responden perempuan.

2. Usia Responden

Berdasarkan hasil peneliian terlihat bahwa responden yang berstatus mahasiswa berdasarkan klasifikasi usia bahwa mayoritas responden berada pada usia 21-25 tahun sebanyak 71 orang $(68 \%)$ sedangkan responden yang berada pada usia $15-20$ tahun sebanyak 34 orang (32\%). Dari presentasi yang ada dalam grafik 4.2 terlihat bahwa pelanggan Starbucks Coffee yang menggunakan Starbucks Card mayoritas berstatus mahasiswa, hal ini disebabkan adanya bergesernya segmentasi dan gaya hidup seseorang yang tinggi.

3. Pendapatan Bulanan

Berdasarkan pendapatan rata-rata responden tiap bulan (grafik 4.3), terdapat 5 orang atau 5\% dari keseluruhan yang menyatakan bahwa pendapatan rata-rata bulannya berkisar < Rp.1.000.000. Setelah itu, sebanyak 49 responden atau sekitar $47 \%$ menyatakan bahwa pendapatan rata-rata bulannya yaitu Rp. 1.000 .000 - Rp. 2.000.000. Selanjutnya, sebanyak 31 responden atau $29 \%$ menyatakan bahwa pendapatan rata-rata bulannya yaitu Rp. 2.000.000 - Rp. 3.000.000. Terakhir yaitu sebanyak 20 orang atau sekitar 19\% menyatakan bahwa pendapatan rata-rata bulannnya yaitu > Rp. 3.000.000.

4. Gerai Starbucks Coffee Sering Dikunjungi

Berdasarkan gerai Starbucks Coffee yang sering dikunjungi responden, terdapat 41 orang atau $21 \%$ yang mengakui bahwa responden sering berkunjung ke gerai Starbucks Coffee Paris Van Java (PVJ). Selain itu, terdapat 15 orang atau $8 \%$ yang mengakui bahwa responden sering berkunjung ke gerai Starbucks Coffee Dipatiukur. Selanjutnya yaitu terdapat 63 responden atau 33\% yang mengakui bahwa sering berkunjung ke gerai Starbucks Coffee Trans Studio Mall (TSM). Kemudian, terdapat 43 responden atau $22 \%$ yang mengakui bahwa sering berkunjung ke gerai Starbucks Coffee Braga City Walk. Lalu, terdapat 23 responden atau $12 \%$ mengaku bahwa responden sering berkunjung ke gerai Starbucks Coffee Cihampelas Walk. Terakhir yaitu terdapat 8 responden atau 4\% yang mengaku bahwa responden sering berkunjung ke gerai Starbucks Coffee Buah Batu.

\section{Hasil Penelitian}

1. Variable Periklanan

Berdasarkan hasil pengolaha, dapat dilihat bahwa skor total periklanan adalah 1237. Jumlah skor tersebut dimasukkan ke dalam garis kontinum, yang pengukurannya ditentukan dengan cara:

Nilai Indeks Maksimum $=5 \times 3 \times 105=1575$

Nilai Indeks Minimum $=1$ x 3 x $105=315$ 
Jarak Interval $=[$ nilai maksimum - nilai minimum $]: 5=(1575-315): 5=252$

Persentase Skor $=[($ total skor $):$ nilai maksimum $] \times 100 \%=(1237: 1575) \times 100 \%=$ $78.53 \%$.

\section{Gambar 2 Garis Kontinum Kriteria Peniliaian Kuisioner}

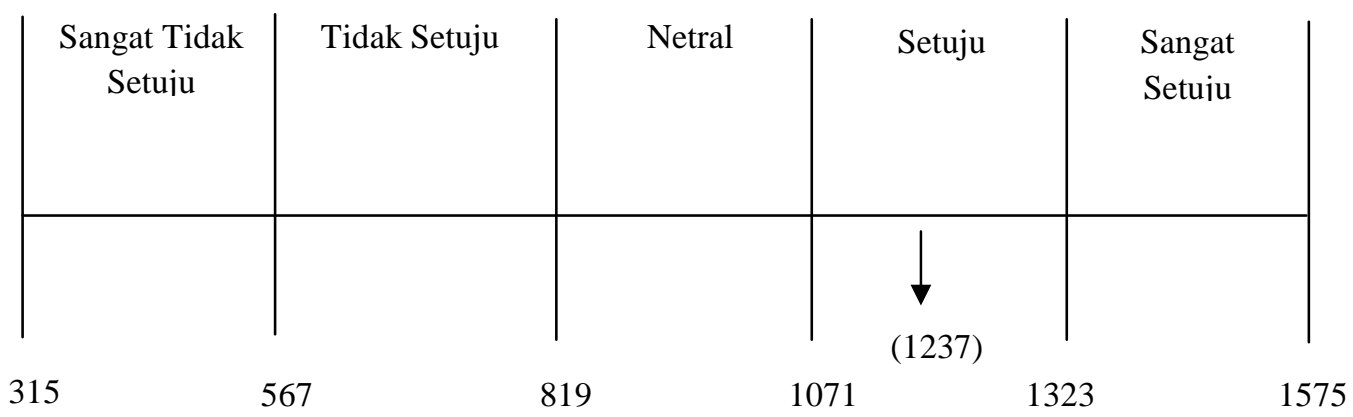

Berdasarkan garis kontinum pada gambar 2 menunjukan dari seluruh total sub variabel periklanan (X1) yang terdiri dari tiga pernyataan, diperoleh hasil akhir sebesar 1237 sehingga berada pada kategori BAIK dengan perolehan skor persentase rata-rata yaitu sebesar $78.53 \%$.

2. Variable Promosi Penjualan

Berdasarkan hasil pengolahan, dapat dilihat bahwa skor total promosi penjualan adalah 2189. Jumlah skor tersebut dimasukkan ke dalam garis kontinum, yang pengukurannya ditentukan dengan cara:

Nilai Indeks Maksimum $=5 \times 5 \times 105=2625$

Nilai Indeks Minimum $=1$ x 5 x $105=525$

Jarak Interval $=[$ nilai maksimum - nilai minimum $]: 5=(2625-525): 5=420$

Persentase Skor $=[($ total skor $):$ nilai maksimum $] \times 100 \%=(2189: 2625) \times 100 \%=$ $83.39 \%$.

\section{Gambar 3 Garis Kontinum Kriteria Peniliaian Kuisioner}

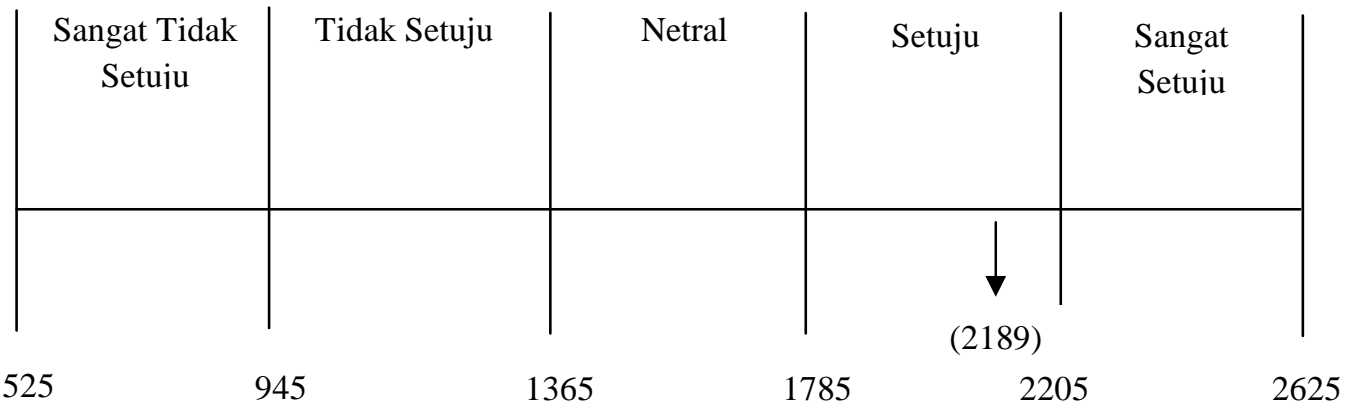

Berdasarkan garis kontinum gambar 3 menunjukan dari seluruh total sub variabel promosi penjualan (X2) yang terdiri dari lima pernyataan, diperoleh hasil akhir 
sebesar 2189 sehingga berada pada kategori BAIK dengan perolehan skor persentase rata-rata yaitu sebesar $83.39 \%$.

3. Variable Personal Selling

Berdasarkan hasil pengolahan, dapat dilihat bahwa skor total personal selling 1725 . Jumlah skor tersebut dimasukkan ke dalam garis kontinum, yang pengukurannya ditentukan dengan cara:

Nilai Indeks Maksimum $=5$ x 4 x $105=2100$

Nilai Indeks Minimum $=1$ x 4 x $105=420$

Jarak Interval $=[$ nilai maksimum - nilai minimum $]: 5=(2100-420): 5=336$

Persentase Skor $=[($ total skor $):$ nilai maksimum $] \times 100 \%=(1725: 2100) \times 100 \%=$ $82.14 \%$.

\section{Gambar 4 Garis Kontinum Kriteria Peniliaian Kuisioner}

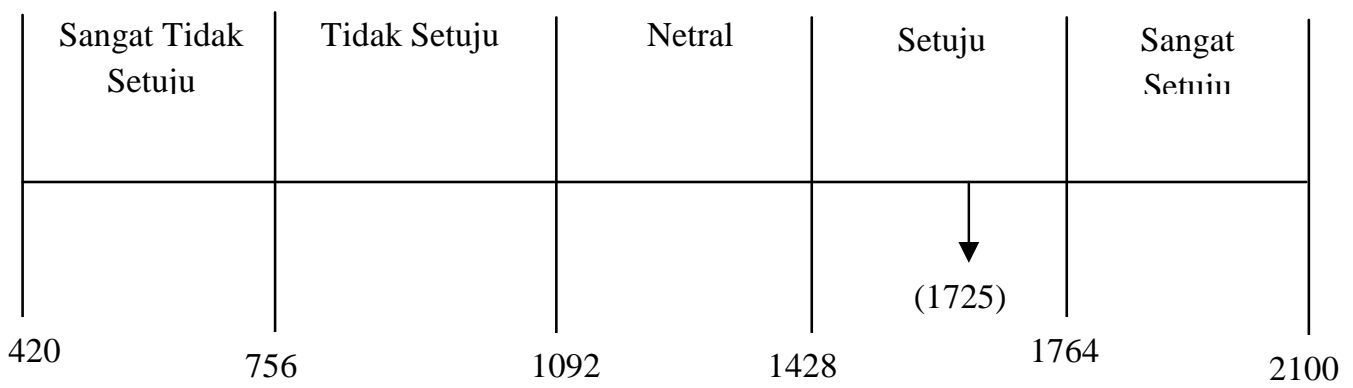

Berdasarkan garis kontinum pada gambar 4 menunjukan dari seluruh total sub variabel Personal Selling (X3) yang terdiri dari empat pernyataan, diperoleh hasil akhir sebesar 1725 sehingga berada pada kategori BAIK dengan perolehan skor persentase rata-rata yaitu sebesar $82.14 \%$.

4. Variable Public Relation

Berdasarkan hasil pengolahan dapat dilihat bahwa skor total public relation adalah 835. Jumlah skor tersebut dimasukkan ke dalam garis kontinum, yang pengukurannya ditentukan dengan cara:

Nilai Indeks Maksimum $=5$ x 2 x $105=1050$

Nilai Indeks Minimum $=1$ x 2 x $105=210$

Jarak Interval $=[$ nilai maksimum - nilai minimum $]: 5=(1050-210): 5=168$

Persentase Skor $=[($ total skor $):$ nilai maksimum $] \times 100 \%=(1725: 1050) \times 100 \%=$ $79.52 \%$. 


\section{Gambar 5 Garis Kontinum Kriteria Peniliaian Kuisioner}

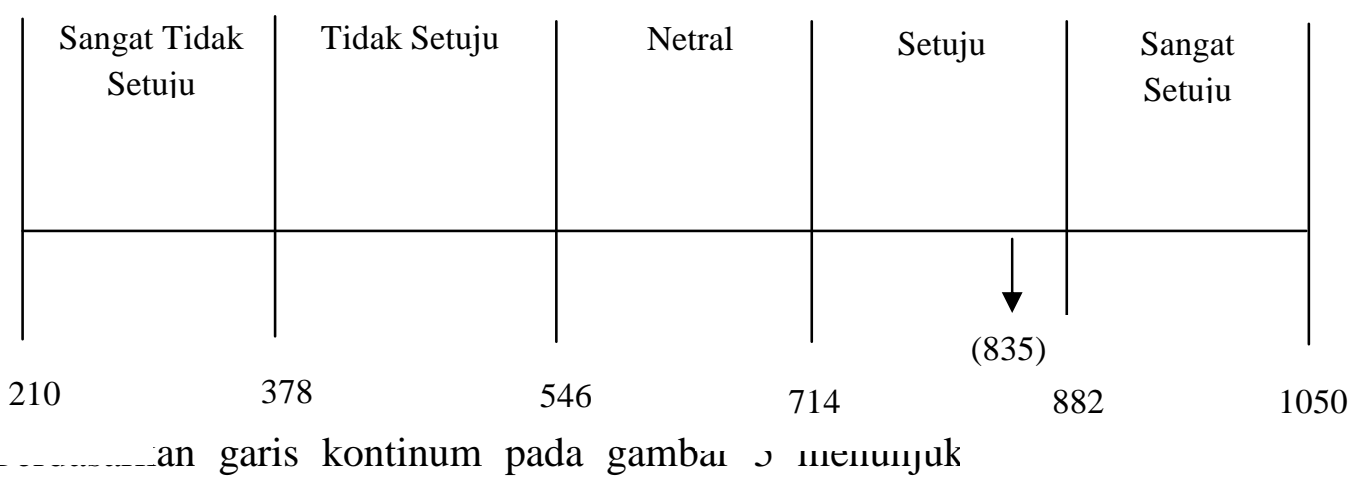

variabel publik relation (X4) yang terdiri dari dua pernyataan, diperoleh hasil akhir sebesar 835 sehingga berada pada kategori BAIK dengan perolehan skor persentase rata-rata yaitu sebesar $79.52 \%$.

5. Variable Direct Marketing dan Marketing via Internet

Berdasarkan hasil pengolahan dapat dilihat bahwa skor total Direct Marketing dan Marketing via Internet adalah 1222. Jumlah skor tersebut dimasukkan ke dalam garis kontinum, yang pengukurannya ditentukan dengan cara:

Nilai Indeks Maksimum $=5 \times 3 \times 105=1575$

Nilai Indeks Minimum $=1 \times 3 \times 105=315$

Jarak Interval $=[$ nilai maksimum - nilai minimum $]: 5=(1575-315): 5=252$

Persentase Skor $=[($ total skor $):$ nilai maksimum $] \times 100 \%=(1222: 1575) \times 100 \%=$ $77.58 \%$.

\section{Gambar 6 Garis Kontinum Kriteria Peniliaian Kuisioner}

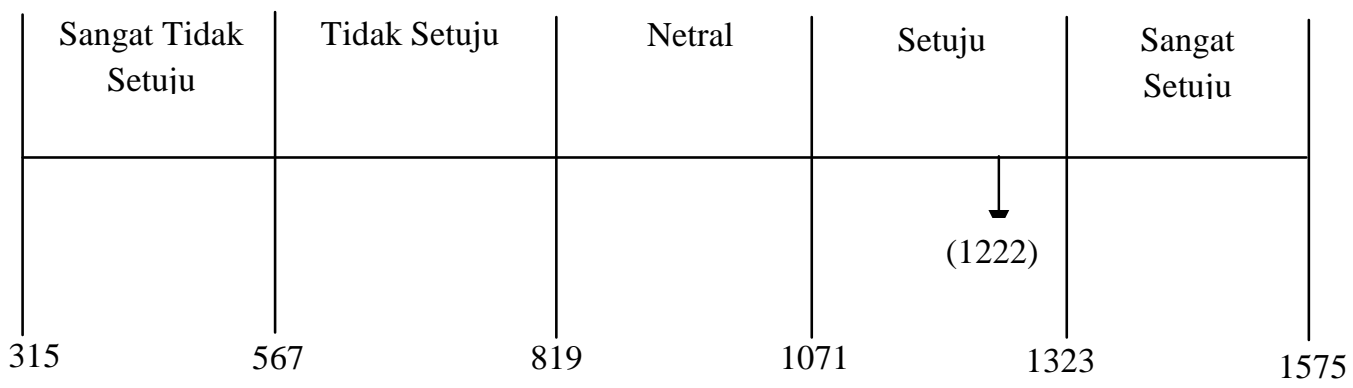

Berdasarkan garis kontinum pada gambar 6 menunjukan dari seluruh total sub variabel Direct Marketing dan Marketing via Internet (X5) yang terdiri dari tiga pernyataan, diperoleh hasil akhir sebesar 1222 sehingga berada pada kategori BAIK dengan perolehan skor persentase rata-rata yaitu sebesar $77.58 \%$.

6. Variable Loyalitas Konsumen

Berdasarkan hasil pengolahan dapat dilihat bahwa skor total Loyalitas Konsumen adalah 1588. Jumlah skor tersebut dimasukkan ke dalam garis kontinum, yang pengukurannya ditentukan dengan cara:

Nilai Indeks Maksimum $=5$ x 4 x $105=2100$

Nilai Indeks Minimum $=1$ x 4 × $105=420$ 
Jarak Interval $=[$ nilai maksimum - nilai minimum $]: 5=(2100-420): 5=336$

Persentase Skor $=[($ total skor $):$ nilai maksimum $] \times 100 \%=(1588: 2100) \times 100 \%=$ $75.61 \%$.

\section{Gambar 7 Garis Kontinum Kriteria Peniliaian Kuisioner}

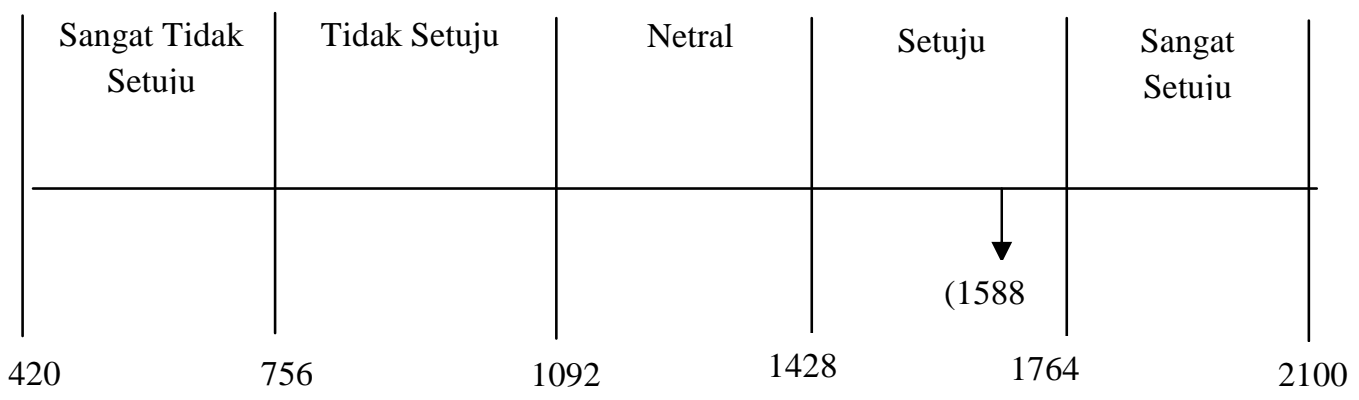

Berdasarkan garis kontinum pada gambar 7 menunjukan dari seluruh total variable Loyalitas Konsumen (Y) yang terdiri dari empat pernyataan, diperoleh hasil akhir sebesar 1588 sehingga berada pada kategori BAIK dengan perolehan skor persentase rata-rata yaitu sebesar $75.61 \%$.

\section{Rekapitulasi Regresi Linear Berganda}

Analisis regresi berganda digunakan untuk mengetahui hubungan antara variable tergantung dipengaruhi oleh dua atau lebih variable independen (X) dengan variable dependen (Y) apakah akan memiliki hasil positif atau tidak dan analisis ini juga bertujuan untuk memprediksi nilai dari variable depeden mengalami kenaikan atau penurunan. Berikut hasil pengujian mengenai pengaruh dari variable independen dan dependen tersebut pada tabel 4:

\section{Tabel 4}

Model Summary

\begin{tabular}{|l|r|r|r|r|}
\hline Model & \multicolumn{1}{|c|}{$\mathrm{R}$} & $\begin{array}{c}\mathrm{R} \\
\text { Square }\end{array}$ & $\begin{array}{c}\text { Adjusted } \\
\mathrm{R} \\
\text { Square }\end{array}$ & $\begin{array}{c}\text { Std. } \\
\text { Error of } \\
\text { the } \\
\text { Estimate }\end{array}$ \\
\hline 1 & $.783^{\mathrm{a}}$ & .613 & .594 & 2.032 \\
\hline
\end{tabular}

a. Predictors: (Constant), DMMI, Periklanan, PSelling, PPenjualan, PRelation

Sumber: Hasil pengolahan data dengan SPSS 21.0 
Pada tabel model summary diatas (tabel 4) menjelaskan bahwa nilai $\mathrm{R}$ atau Multiple $\mathrm{R}$ menunjukkan korelasi berganda antara variable bebas dengan variable tergantung sebesar 0.783 (78.3\%). Kemudian untuk nilai R Square atau koefisien determinasi dapat dijelaskan bahwa variable loyalitas konsumen dapat dijelaskan oleh strategi komunikasi pemasaran sebesar 0.613 atau $61.3 \%$ atau variable strategi komunikasi pemasaran dapat mempengaruhi loyalitas konsumen. Sedangkan sisanya sebesar 0.387 atau $38.7 \%$ dipengaruhi oleh faktor lainnya. Kemudian analisis selanjutnya ialah untuk mengetahui apakah variable independen strategi komunikasi pemasaran mempengaruhi variable dependen loyalitas konsumen akan dijelaskan dalam tabel 5 sebagai berikut:

Tabel 5 Uji ANOVA

\begin{tabular}{|l|r|r|r|r|r|}
\hline Model & \multicolumn{1}{|c|}{$\begin{array}{c}\text { Sum of } \\
\text { Squares }\end{array}$} & df & $\begin{array}{c}\text { Mean } \\
\text { Square }\end{array}$ & $\mathrm{F}$ & Sig. \\
\hline 1 Regression & 629.897 & 5 & 125.979 & 29.188 & $.000^{\mathrm{b}}$ \\
Residual & 427.303 & 99 & 4.316 & & \\
Total & 1057.200 & 104 & & & \\
\hline
\end{tabular}

a. Dependent Variable: LKonsumen

b. Predictors: (Constant), DMMI, Periklanan, PSelling, PPenjualan, PRelation

Berdasarkan tabel 5 terlihat bahwa nilai signifikansi atau probabilitas .000 lebih kecil dari 0.05. Nilai signifikansi merupakan nilai yang menunjukkan titik kesalahan yang terjadi jika nilai $\mathrm{F}$ hitung sebesar 29.188. Jadi dapat disimpulkan bahwa variable bebas secara simultan mampu menjelaskan perubahan pada variable dependen dinyatakan cocok atau fit. Setelah itu, berikut hasil untuk mengetahui nilai koefisien regresi dari model penelitian konstruk strategi komunikasi pemasaran terhadap loyalitas konsumen dalam tabel 6:

\section{Tabel 6}

\section{KOEFIENSI REGRESI VARIABEL STRATEGI KOMUNIKASI PEMASARAN TERHADAP LOYALITAS KONSUMEN Coefficients $^{\mathrm{a}}$}

\begin{tabular}{|l|c|c|c|c|c|}
\hline & \multicolumn{2}{|c|}{$\begin{array}{c}\text { Unstandardized } \\
\text { Coefficients }\end{array}$} & $\begin{array}{c}\text { Standardized } \\
\text { Coefficients }\end{array}$ & & \\
\cline { 2 - 5 } Model & $\mathrm{B}$ & $\begin{array}{c}\text { Std. } \\
\text { Error }\end{array}$ & Beta & $\mathrm{t}$ & Sig. \\
\hline 1 (Constant) & .888 & 1.503 & & .591 & .556 \\
\hline
\end{tabular}




\begin{tabular}{|l|r|r|r|r|r|} 
Periklanan & -.014 & .146 & -.009 & -.093 & .926 \\
PPenjualan & .456 & .109 & .353 & 4.184 & .000 \\
PSelling & .394 & .121 & .006 & 3.263 & .002 \\
PRelation & .467 & .252 & .229 & 1.851 & .067 \\
DMMl & .310 & .146 & .268 & 2.124 & .003 \\
\hline
\end{tabular}

a. Dependent Variable: LKonsumen

Berdasarkan tabel 6, dapat dilihat bahwa persamaan regresi yang didapat dari penelitian ini adalah $\mathrm{Y}=0.888-0.014 \mathrm{X}_{1}+0.456 \mathrm{X}_{2}+0.394 \mathrm{X}_{3}+0.467 \mathrm{X}_{4}+0.310 \mathrm{X}_{5}+\varepsilon$. Nilai $\mathrm{t}$ digunakan untuk mengetahui apakah variable bebas tersebut signifikan atau tidak. Nilai $\mathrm{t}$ untuk jumlah responden sebanyak 105 orang (dengan degree of freedom $=\mathrm{n}-1$ Sig. 0.05) adalah sebesar 1.983 (Malhotra, et. al,) sehingga variable independen yang berpengaruh secara signifikan adalah yang memiliki nilai t diatas +1.983 dan dibawah 1.983. Nilai signifikansi merupakan angka yang menunjukkan besarnya tingkat kesalahan pada nilai t yang diperoleh. Jika nilai t semakin besar maka nilai Sig. semakin kecil. Dilihat dari tabel 6 dapat diketahui bahwa nilai sig. dari variable periklanan (X1) yaitu 0.926 dengan t-periklanan yaitu -0.093 , karena nilai Sig. variabel periklanan 0.926 lebih besar dari 0.05 dan koefisiennya bernilai negatif maka disimpulkan bahwa variable periklanan memiliki pengaruh negatif terhadap loyalitas konsumen. Selanjutnya untuk variabel promosi penjualan (X2) diketahui bahwa nilai Sig. sebesar 0.000 dengan t-promosi penjualan yaitu 4.184, karena nilai Sig. promosi penjualan 0.000 lebih kecil dari 0.05 dan arah koefisiennya positif maka dapat disimpulkan bahwa variable promosi penjualan memiliki pengaruh positif terhadap loyalitas konsumen. Kemudian untuk variabel personal selling (X3) diketahui bahwa nilai sig. personal selling yaitu 0.002 dengan t-personal selling sebesar 3.263, karena nilai sig. personal selling lebih kecil dari nilai 0.05 dan arah koefisiennya bernilai positif sehingga dapat disimpulkan bahwa variabel personal selling memiliki pengaruh positif terhadap loyalitas konsumen. Lalu, untuk variabel public relation (X4) diketahui bahwa nilai sig. public relation yaitu 0.067 dengan t-public relation sebesar 1.851, karena nilai sig. public relation lebih besar dari nilai 0.05 dan arah koefisiennya bernilai positif sehingga dapat disimpulkan bahwa variabel public relation memiliki pengaruh negatif terhadap loyalitas konsumen. Sedangkan untuk variabel direct marketing dan pemasaran via internet (X5) diketahui bahwa nilai sig. direct marketing dan pemasaran via internet yaitu 0.003 dengan t-personal selling sebesar 2.124, karena nilai sig. direct marketing dan pemasaran via internet lebih kecil dari nilai 0.05 dan arah koefisiennya bernilai positif sehingga dapat disimpulkan bahwa variabel direct marketing dan pemasaran via internet memiliki pengaruh positif terhadap loyalitas konsumen.

Jadi, dapat disimpulkan bahwa variabel yang paling berpengaruh positif terhadap loyalitas konsumen yaitu variabel promosi penjualan (X2) dengan nilai signifikansi sebesar 0.000. Kemudian variabel personal selling (X3) dengan nilai signifikansi sebesar 0.002 dan variabel direct marketing dan pemasaran via internet (X5) dengan nilai signifikansi sebesar 0.003 . 


\section{Hasil Uji Hipotesis}

Analisis ini bertujuan untuk menguji hipotesis berupa dugaan sementara peneliti. Dalam penelitian ini ada lima hipotesis yang akan diuji. Analisis ini menggunakan uji statistik t dimana dasar tidak ditolaknya hipotesis yang memiliki nilai t diatas +1.983 dan dibawah -1.983 serta yang memiliki nilai signifikansi diatas 0.05 .

1) Pengaruh antara sub variable periklanan (X1) dan loyalitas konsumen (Y)

Hipotesis 1 akan menguji apakah terdapat pengaruh antara periklanan terhadap loyalitas konsumen. Berdasarkan uji statistik t, dapat diketahui bahwa nilai sig. dari variable periklanan (X1) yaitu 0.926 dengan t-periklanan yaitu -0.093 , karena nilai Sig. variabel periklanan 0.926 lebih besar dari 0.05 dan koefisiennya bernilai negatif maka disimpulkan bahwa variable periklanan tidak memiliki pengaruh terhadap loyalitas konsumen berstatus mahasiswa pengguna Starbucks Card di kota Bandung.

2) Pengaruh antara sub variable promosi penjualan (X2) dan loyalitas konsumen (Y)

Hipotesis 2 akan menguji apakah terdapat pengaruh antara promosi penjualan terhadap loyalitas konsumen. Berdasarkan uji statistik $t$, dapat diketahui bahwa nilai sig. dari variabel promosi penjualan (X2) sebesar 0.000 dengan t-promosi penjualan yaitu 4.184, karena nilai Sig. promosi penjualan 0.000 lebih kecil dari 0.05 dan arah koefisiennya positif maka dapat disimpulkan bahwa variable promosi penjualan memiliki pengaruh terhadap loyalitas konsumen berstatus mahasiswa pengguna Starbucks Card di kota Bandung.

3) Pengaruh antara sub variable personal selling (X3) dan loyalitas konsumen (Y)

Hipotesis 3 akan menguji apakah terdapat pengaruh antara personal selling terhadap loyalitas konsumen. Berdasarkan uji statistik $t$, dapat diketahui bahwa nilai sig. dari variabel personal selling (X3) diketahui bahwa nilai sig. personal selling yaitu 0.002 dengan t-personal selling sebesar 3.263, karena nilai sig. personal selling lebih kecil dari nilai 0.05 dan arah koefisiennya bernilai positif sehingga dapat disimpulkan bahwa variabel personal selling memiliki pengaruh terhadap loyalitas konsumen berstatus mahasiswa pengguna Starbucks Card di kota Bandung.

4) Pengaruh antara sub variable public relation (X4) dan loyalitas konsumen (Y) Hipotesis 4 akan menguji apakah terdapat pengaruh antara public relation terhadap loyalitas konsumen. Berdasarkan uji statistik t, dapat diketahui bahwa nilai sig. dari variabel public relation (X4) diketahui bahwa nilai sig. public relation yaitu 0.067 dengan t-public relation sebesar 1.851, karena nilai sig. public relation lebih besar dari nilai 0.05 dan arah koefisiennya bernilai positif sehingga dapat disimpulkan bahwa variabel public relation tidak memiliki pengaruh terhadap loyalitas konsumen berstatus mahasiswa pengguna Starbucks Card di kota Bandung.

5) Pengaruh antara sub variable direct marketing dan marketing via internet (X5) dan loyalitas konsumen (Y)

Hipotesis 5 akan menguji apakah terdapat pengaruh antara direct marketing dan marketing via internet terhadap loyalitas konsumen. Berdasarkan uji statistik t, variabel direct marketing dan pemasaran via internet (X5) diketahui bahwa nilai 
sig. direct marketing dan pemasaran via internet yaitu 0.003 dengan t-personal selling sebesar 2.124, karena nilai sig. direct marketing dan pemasaran via internet lebih kecil dari nilai 0.05 dan arah koefisiennya bernilai positif sehingga dapat disimpulkan bahwa variabel direct marketing dan pemasaran via internet memiliki pengaruh pengaruh terhadap loyalitas konsumen berstatus mahasiswa pengguna Starbucks Card di kota Bandung.

\section{Uji Asumsi Klasik}

\section{Uji Asumsi Klasik Normalitas}

\section{Gambar 8 Histogram Uji Normalitas}

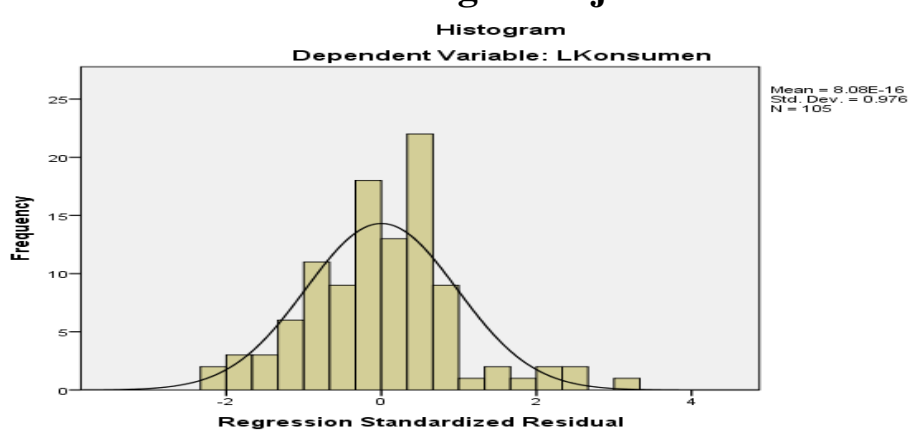

Sumber: Hasil pengolahan dengan SPSS 21.0 for Windows

Berdasarkan tampilan histogram diatas dapat dilihat bahwa kurva dependent (Loyalitas Konsumen) dan regression standardized residual membentuk gambar seperti lonceng. Oleh karena itu dapat disimpulkan bahwa analisis regresi layak digunakan walaupun sedikit kemiringan.

\section{Gambar 9 P-P Plot Uji Normalitas}

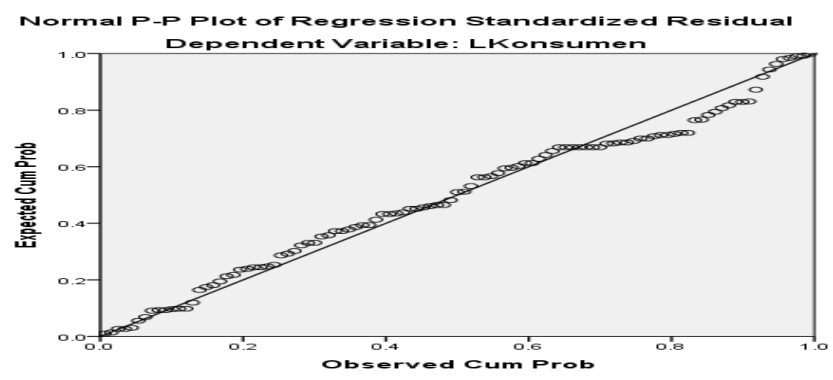

Sumber: Hasil pengolahan dengan SPSS 21.0 for Windows

Berdasarkan tampilan Normal P-P Plot Regression Standardized terlihat bahwa titik-titik menyebar disekitar garis diagonal. Oleh karena itu berdasarkan uji normalitas, analisis regresi layak digunakan meskipun terlihat sedikit plot yang menyimpang dari garis diagonal. 


\section{Uji Asumsi Klasik Heteroskedastisitas}

\section{Gambar 10 Heteroskedastisitas}

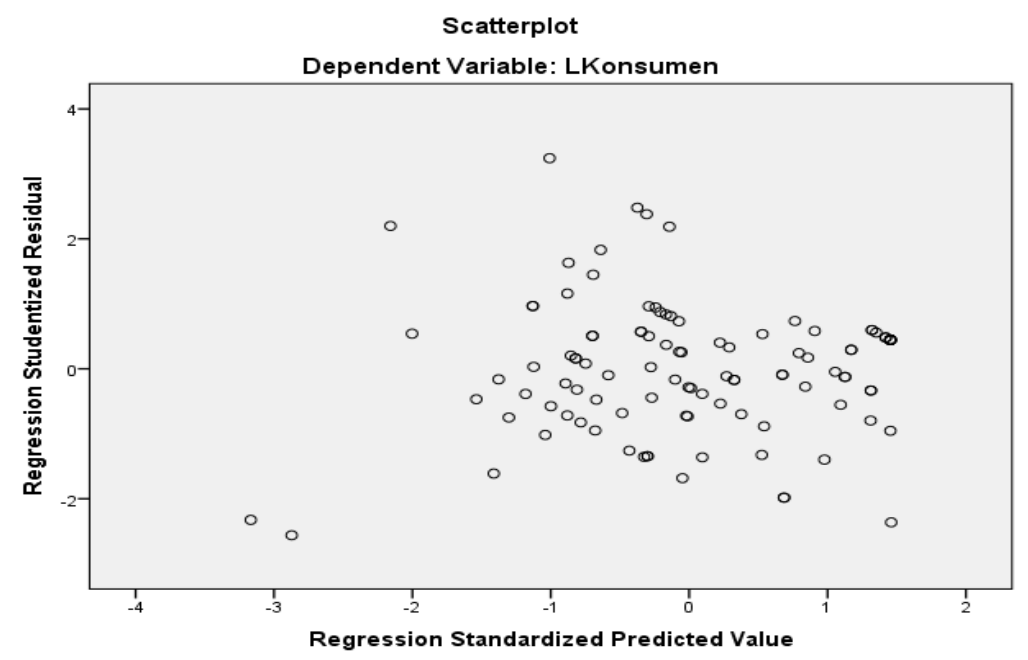

Sumber: Hasil pengolahan dengan SPSS 21.0 for Windows

Berdasarkan gambar 10, terlihat bahwa plot menyebar secara acak di atas maupun di bawah angka nol pada sumbu Regression Studentized Residual. Maka dari itu dapat disimpulkan bahwa pada model regresi yang terbentuk dinyatakan tidak terjadi gejala heteroskedastisitas. Uji asumsi klasik dengan metode grafik ini memiliki beberapa kelemahan, diantaranya yaitu selain memberikan penilaian yang subjektif, metode ini sulit diinterpretasikan jika jumlah pengamatannya sedikit.

\section{Uji Asumsi Klasik Linieritas}

Gambar 11 Uji Asumsi Klasik Linieritas

scatterplot

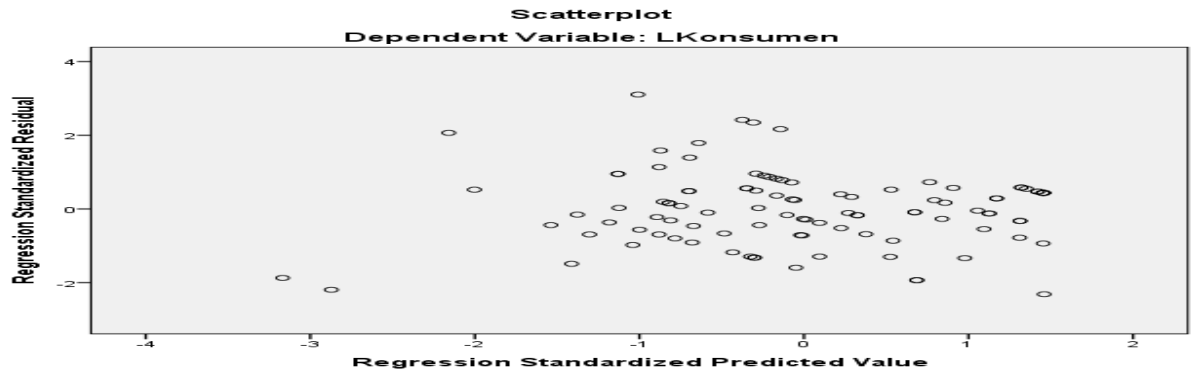

Sumber: Hasil pengolahan dengan SPSS 21.0 for Windows

Berdasarkan gambar 11, terlihat bahwa plot menyebar secara acak di atas maupun di bawah angka nol pada sumbu Regression Standartized Residual. Maka dari itu dapat disimpulkan bahwa pada model regresi yang terbentuk dinyatakan linier. 


\section{KESIMPULAN DAN SARAN Kesimpulan}

Sebagaimana dengan tujuan penulisan penelitian ini yaitu untuk mengetahui adakah pengaruh antara strategi komunikasi pemasaran Starbucks Card terhadap loyalitas konsumen, selain itu untuk mengetahui bagaimana strategi komunikasi pemasaran Starbucks Card dan untuk mengetahui seberapa besar pengaruh strategi komunikasi pemasaran Starbucks Card terhadap loyalitas konsumen. Maka dari itu peneliti berusaha membuat kesimpulan berdasarkan hasil analisis data yang sudah dilakukan dalam bab sebelumnya. Kesimpulan tersebut dapat diketahui bahwa adanya hubungan yang kuat antara variabel strategi komunikasi pemasaran terhadap variabel loyalitas konsumen. Selain itu, variabel strategi komunikasi pemasaran memiliki pengaruh terhadap adanya sebuah pembentukan loyalitas pelanggan berstatus mahasiswa yang menggunakan Starbucks Card. Dari hasil penelitian diketahui bahwa sub variabel promosi penjualan, personal selling dan direct marketing dan pemasaran via internet memiliki pengaruh terhadap loyalitas konsumen. Hal ini dibuktikan dengan melakukan uji hipotesis dalam analisis koefisien regresi variabel strategi komunikasi pemasaran. Sub variabel promosi penjualan memiliki pengaruh terbesar terhadap loyalitas konsumen dengan rata-rata sebesar $83.39 \%$ dan indikator tertinggi adalah PPenjualan 1 (86.85\%) yaitu Starbucks memberikan penawaran khusus dalam jangka waktu tertentu bagi para pengguna Starbucks Card. Sedangkan sub variabel kedua tertinggi yaitu personal selling dengan rata-rata sebesar $82.14 \%$ dan indikator tertinggi adalah PSelling $2(88.76 \%)$ yaitu pegawai Starbucks menguasai informasi mengenai Starbucks Card. Untuk sub variabel ketiga tertinggi yaitu Direct Marketing dan Pemasaran via Internet dengan rata-rata $77.58 \%$ dan indikator tertinggi adalah DMMI 1 (80\%) yaitu Starbucks selalu menawarkan promosi terbaru melalui e-mail kepada para pemegang kartu Starbucks.

\section{Saran}

Berdasarkan penelitian yang telah peneliti lakukan dapat diketahui bahwa berbagai strategi komunikasi pemasaran yang telah dilakukan oleh Starbucks Coffee guna meningkatkan loyalitas konsumen dalam menggunakan kartu meber Starbucks telah berjalan dengan baik dan memiliki respon yang baik oleh para penggunanya. Alangkah lebih baik apabila Starbucks Coffee lebih mempertahankan hal tersebut agar dapat mempertahankan konsumen yang loyal maupun untuk menarik konsumen baru.

\section{DAFTAR PUSTAKA}

Aditia. R, Cakra. 2011. Pengaruh Promosi Penjualan Terhadap Loyalitas Konsumen. Skripsi. Universitas Indonesia, Depok.

Arini, Nimas. N. D. 2013. Setelah 11 Tahun, Starbucks Luncurkan Starbukcs Card.http://swa.co.id/swa/business-strategy/setelah-11-tahun-starbucksluncurkan-starbucks-card. 06 September 2016.

Bajari, Atwar. 2015. Metode Penelitian Komunikasi. Bandung : PT. Remaja Rosdakarya

Caesario, S. 2012. Rancangan Program Komunikasi Pemasaran Terpadu Starbucks Coffee Indonesia Periode 2013. Skripsi. Universitas Indonesia, Depok.

Darmawangsa, B. A.A., I. Gusti. A. K. S.A. 2015. Pengaruh Komunikasi Pemasaran dan Ekuitas Merek Terhadap Loyalitas Konsumen. E-Jurnal Manajemen Unud 4(8): 2163-2175. 
D. Uncles, M., Grahame. R. D., Kathy. H. 2003. Customer Loyalty and Customer Loyalty Programs. Journal of Consumer Marketing 20(4): 294-316.

Griffin, Jill. 2005. Customer Loyalty. Jakarta : Erlangga.

Hermawan, Agus. 2012. Komunikasi Pemasaran. Jakarta : Erlangga.

Hallowell, R. 1996. The Relationship of Customer Satisfaction, Customer Loyalty, and Profitability: an empirical study. Harvard Business School: 27-42.

Imasari, K. dan Kezia. K. Kurniawan. 2011. Pengaruh Customer Relationship Management Terhadap Loyalitas Pelanggan Pada PT BCA Tbk. Fokus Ekonomi (FE) 10(3): 183-192.

Kotler, Philip \& Gary Armstrong. 2012. Principles of Marketing Fourteenth Edition. England : Pearson Education Limited.

Kotler, Philip \& Kevin Lane Keller. 2009. Manajemen Pemasaran. England : Pearson Education, Inc.

Limakrisna, N. 2008. Pengaruh Komunikasi Pemasaran dan Kerelasian Nasabah Terhadap Loyalitas Nasabah. Jurnal Ekonomi Bisnis 13(1): 68-79.

L. Duffy, Dennis. 2003. Internal and Eksternal Factors Which Affect Customer Loyalty. Journal of Consumer Marketing 20(5): 480-485.

Pratiwi, D.H., Pengaruh Efektifitas Periklanan Terhadap Loyalitas Konsumen IM3. Skripsi. Universitas Telkom, Bandung, Jawa Barat.

Rahmatullah. 2009. Pengaruh Komunikasi Pemasaran Terhadap Loyalitas Nasabah (Studi Kasus Bank YXZ Syariah Cabang Bogor). Islamic Finance and Business 4(2): 808-826.

Sedarmayanti. 2002. Metode Penelitian. Jakarta: Mandar Maju.

Stella V.K, Angeline. 2014. Strategi Komunikasi Pemasaran KICK dalam Meningkatkan Brand Equity. Skripsi. Universitas Telkom, Bandung, Jawa Barat.

Sulaksana, Uyung. 2003. Integrated Marketing Communication. Yogyakarta : Pustaka Belajar.

Sutisna. 2001. Perilaku Konsumen dan Komunikasi Pemasaran.Bandung : PT Remaja Rosdakarya..

Sugiyono. 2016. Metode Penelitian. Bandung : Alfabeta.

Suharsaputra, Uhar. 2012. Metode Penelitian. Bandung : PT Refika Aditama

Sudaryono. 2014. Perilaku Konsumen. Jakarta : Lentera Ilmu Cendikia.

Suliyanto. 2011. Ekonometrika Terapan: Teori \& Terapan SPSS. Yogyakarta: Andi Offset.

Susanty, A. dan Eirene. 2015. The Relationship between Brand Equity, Customer Satisfaction and Brand Loyalty on Coffee Shop: Study of Exelso and Starbucks. Asean Marketing Journal 7(1): 14-27.

Starbucks.co.id. 05 Oktober 2016

Wibisono, Dermawan. 2013. Panduan Penyusunan Skripsi, Tesis dan Disertasi. Yogyakarta : C.V Andi Offset

Wahyu. 2011. Riset Pemasaran dan Konsumen. Bogor : PT IPB Press

Wibowo, H.S., Uud, W., Pramono, B. 2012. Strategi Komunikasi Pemasaran Website www.bandungreview.com. Jurnal Mahasiswa Universitas Padjajaran 10(3): 113. 
Wijaya, Serli. Thio, S. 2008. Implementasi Membership Card dan Pengaruhnya dalam meningkatkan Loyalitas Pengunjung Restoran di Surabaya.Eksekutif 5(1): 1325.

Yustika. A., Desbrina. 2009. Pengaruh Bauran Promosi Terhadap Loyalitas Konsumen Produk Telkom Flexi. Skripsi. Univeritas Muhammadiyah Malang. Malang, Jawa Timur. 